\title{
Introducing volume 8 of Neurodegenerative Disease Management
}

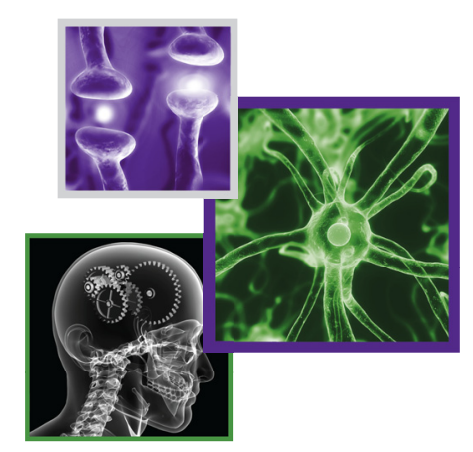

Laura Dormer*,1

${ }^{1}$ Future Medicine Ltd, Unitec House, London N3 1QB, UK

* Author for correspondence: I.dormer@futuremedicine.com

Welcome to the eighth volume of Neurodegenerative Disease Management. At the start of a new volume, it is interesting to look back at which content proved most popular in 2017, and also to take a look forward to the content of this issue and beyond.

First draft submitted: 19 December 2017; Published online: 5 February 2018

Keywords: author demographics $\bullet$ neurodegenerative disease $\bullet$ top articles

\section{In this issue}

The first issue of 2018 kicks off with an Editorial from Popugaeva and Bezprozvanny, discussing the existence of neuronal store-operated calcium channels and their potential importance for neuronal function [1].

At the end of 2017, the Annual European Committee for Treatment and Research in Multiple Sclerosis Congress took place in Paris. Over the next two issues of Neurodegenerative Disease Management, we will be featuring interviews with some of the individuals who presented their research in France. In this issue, we speak to Dr Shibeshih Belachew (Roche, Basel, Switzerland) about ocrelizumab, and Roche's efforts to advance the understanding of progression in multiple sclerosis (MS) [2]. A second interview with Dr Sarah Sheikh (Biogen, MA, USA) discusses opicinumab, the post hoc analysis to the SYNERGY trial and the topic of neurorepair [3].

In a case series article, Ramanathan and Rana review patients with primary lateral sclerosis treated at their hospital [4]. Two research articles are also presented: the first, from Fadare et al., examines epilepsy medication adherence in Nigeria [5]; the second is from Spreadbury and Kipps, in which the authors investigate and identify important issues in young-onset dementia care provision from a healthcare provider perspective [6].

The issue is completed with a review article from Pelak and Hills, which focuses on the anterior afferent visual pathways in Alzheimer's disease (AD) and the measures used for assessment [7].

\section{Content highlights of 2017}

Our most popular content in 2017 covers a broad range of the scope of Neurodegenerative Disease Management (Table 1). The most popular topic proved to be MS, with four of the top ten articles of the year on this topic. However, among these four, there was a wide variety of content, including a drug evaluation on teriflunomide [8]; an interview with Biogen's senior vice president and head of Worldwide Medical, Dr Ralph Kern, discussing their portfolio and research in MS [9]; a research article applying the Delphi method to the ALLOW study [10]; and a Systematic Review examining the effect of exercise interventions on fatigue [11].

Parkinson's disease (PD) was represented by two research articles in the top ten, both from the same group of authors, with one paper examining ropinirole prolonged release in advanced PD [14], and the other looking at the same drug in early stage PD [15].

One of the most popular articles of 2017, and the only review article in the top ten, discusses a rare neurodegenerative disease - chronic inflammatory demyelinating polyneuropathy (CIDP). In this article, Katzberg et al. summarize the topics discussed at a scientific symposium held in conjunction with the International Congress of Neuromuscular Diseases in Toronto, Canada (in July 2016), including: advances in electrodiagnostic and clinical measures of disease activity in CIDP; and use of real-time high-resolution ultrasound as a surrogate biomarker of disease activity and therapeutic efficacy in CIDP [12]. 


\begin{tabular}{|c|c|c|c|c|c|c|}
\hline Rank & Article type & Title & Authors & Volume(issue) & $\begin{array}{l}\text { Altmetric } \\
\text { score }\end{array}$ & Ref. \\
\hline 1 & Drug evaluation & $\begin{array}{l}\text { Teriflunomide in multiple sclerosis: an } \\
\text { update }\end{array}$ & Miller AE & $7(1)$ & 1 & [8] \\
\hline 2 & Review & $\begin{array}{l}\text { Measuring disease activity and clinical } \\
\text { response during maintenance therapy in } \\
\text { CIDP: from ICE trial outcome measures to } \\
\text { future clinical biomarkers }\end{array}$ & $\begin{array}{l}\text { Katzberg HD, Latov N, Francis } \mathrm{O} \text {, } \\
\text { Walker FO }\end{array}$ & $7(2)$ & 1 & [12] \\
\hline 3 & Editorial & $\begin{array}{l}\text { Activation of Nrf2 signaling as a common } \\
\text { treatment of neurodegenerative diseases }\end{array}$ & $\begin{array}{l}\text { Dinkova-Kostova AT, Kazantsev } \\
\text { AG }\end{array}$ & $7(2)$ & 4 & [13] \\
\hline 4 & Research article & $\begin{array}{l}\text { A randomized, fixed-dose, dose-response } \\
\text { study of ropinirole prolonged release in } \\
\text { advanced Parkinson's disease }\end{array}$ & $\begin{array}{l}\text { Zesiewicz TA, Chriscoe S, Jimenez } \\
\text { T, Upward J, Davy M, VanMeter S }\end{array}$ & $7(1)$ & 1 & [14] \\
\hline 5 & Interview & $\begin{array}{l}\text { Biogen's portfolio and research efforts in } \\
\text { multiple sclerosis: an interview with Dr } \\
\text { Ralph Kern }\end{array}$ & Kern $\mathrm{R}$ & $7(1)$ & 2 & [9] \\
\hline 6 & Research article & $\begin{array}{l}\text { A fixed-dose, dose-response study of } \\
\text { ropinirole prolonged release in early stage } \\
\text { Parkinson's disease }\end{array}$ & $\begin{array}{l}\text { Zesiewicz TA, Chriscoe S, Jimenez } \\
\text { T, Upward J, VanMeter S }\end{array}$ & $7(1)$ & 1 & [15] \\
\hline 7 & Interview & $\begin{array}{l}\text { Identifying therapeutic targets for } \\
\text { Alzheimer's disease with big data }\end{array}$ & Ertekin-Taner N & $7(2)$ & 14 & [16] \\
\hline 8 & Research article & $\begin{array}{l}\text { A survey-based study identifies common } \\
\text { but unrecognized symptoms in a large } \\
\text { series of juvenile Huntington's disease }\end{array}$ & $\begin{array}{l}\text { Moser AD, Epping E, Espe-Pfeifer } \\
\text { Pet al. }\end{array}$ & $7(5)$ & 2 & [17] \\
\hline 9 & Research article & $\begin{array}{l}\text { Subcutaneous peginterferon } \beta-1 \text { a } \\
\text { injection-site reaction experience and } \\
\text { mitigation: Delphi analysis of the ALLOW } \\
\text { study }\end{array}$ & Hendin B, Huang D, Wray S et al. & $7(1)$ & 1 & [10] \\
\hline 10 & Systematic review & $\begin{array}{l}\text { Effect of exercise interventions on } \\
\text { perceived fatigue in people with multiple } \\
\text { sclerosis: synthesis of meta-analytic reviews }\end{array}$ & $\begin{array}{l}\text { Safari R, van der Linden } M L \text {, } \\
\text { Mercer TH }\end{array}$ & $7(3)$ & 3 & [11] \\
\hline
\end{tabular}

Another interview that proved popular in 2017 focused on AD, and the popular topic of big data. In issue 2 of 2017, we spoke to N Ertekin-Taner (Mayo Clinic, FL, USA) and discussed her work using big data to generate testable hypotheses regarding novel drug and biomarker targets in $\mathrm{AD}$ [16].

Huntington's disease is generating some exciting research at present, and in issue 5 Moser $e t$ al. looked at the rarer juvenile Huntington's disease. Their study examined a cluster of symptoms considered to be common, but under-recognized in juvenile Huntington's disease: pain, itching, sleeping difficulties, psychosis and tics [17].

The final article in our top ten of 2017 was an editorial, looking at neurodegenerative disease more broadly - in this case, discussing the transcription factor, $\mathrm{Nrf2}$, and its potential as a therapeutic targeting to counteract neurodegeneration [13].

2017 also saw the publication of a supplementary issue of Neurodegenerative Disease Management, featuring the proceedings of the 2017 Multiple Sclerosis Experts Summit, which took place in Barcelona. In his foreword, conference chair R Linker summarizes the key scientific highlights of the event [18].

As always, a wide array of content was published in volume 7, addressing the broad range of interests of those working in the field.

\section{Demographics of contributors}

As well as a broad range of topics, Neurodegenerative Disease Management is also pleased to represent contributors from a broad geographic area. In 2017, as usual, we featured a large proportion of authors from the UK and USA. However, it is also great to see contributors from elsewhere in Europe, Asia and the rest of the world. Figure 1 shows more detail on this, and we look forward to receiving submissions in 2018 from around the world.

\section{Partnership with Publons}

Providing additional added-value services for our authors has always been a priority for us. However, at the end of 2016, we were pleased to be able to form a partnership with Publons (winners of the 2017 Association for Learned 


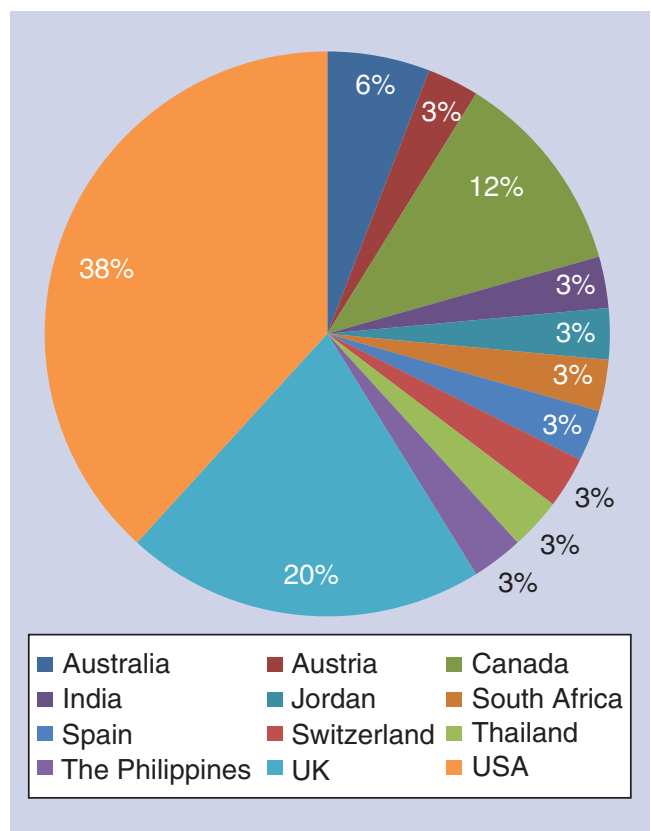

Figure 1. Author demographics for Neurodegenerative Disease Management in 2017.

and Professional Society Publishers Award for Innovation in Publishing) [19], to more fully recognize and give credit to our peer reviewers, who play such a vital role in underpinning the quality of our journal. Neurodegenerative Disease Management reviewers benefit from a seamless integration within the ScholarOne Manuscripts system used to complete their review, allowing them to simply opt in during the review process. Their reviews are then assigned to their verified profile on Publons, in a format they can include in promotion and funding applications, thereby allowing formal recognition for the work they have completed.

\section{New website launch}

In July 2017, we were pleased to unveil our newly designed website. The methods our readers use to access the journal have moved on a great deal in recent years, and the new website has been designed with this in mind; new features help readers to quickly and easily navigate the site, provide new social and sharing capabilities and provide well-structured pages regardless of the device being used to access the articles [20].

\section{Conclusion}

We are delighted with the content published in our 2017 volume, and in particular, it was good to meet many of our readers at various events - including the Alzheimer's Association International Conference and the Society for Neuroscience's Neuroscience 2017 - along with our colleagues from partner website Neuro Central [21]. As always, feedback from our readers is welcome and we are happy to receive any presubmission enquiries if you are interested in submitting your work to us.

\section{Financial \& competing interests disclosure}

L Dormer is an employee of Future Medicine Ltd. The author has no other relevant affiliations or financial involvement with any organization or entity with a financial interest in or financial conflict with the subject matter or materials discussed in the manuscript apart from those disclosed.

No writing assistance was utilized in the production of this manuscript.

\section{References}

1. Popugaeva E, Bezprozvanny I. STIM proteins as regulators of neuronal store-operated calcium influx. Neurodegener. Dis. Manag. 8(1), 5-7 (2018).

2. Belachew S. Advancing the understanding of progression in multiple sclerosis: an interview with Shibeshih Belachew. Neurodegener. Dis. Manag. 8(1), 9-12 (2018).

3. Sheikh SI. The exciting field of neuro-repair in multiple sclerosis: an interview with Sarah Sheikh. Neurodegener. Dis. Manag. 8(1), 13-15 (2018). 
4. Ramanathan RS, Rana S. Demographics and clinical characteristics of primary lateral sclerosis: case series and a review of literature. Neurodegener. Dis. Manag. 8(1), 17-23 2018).

5. Fadare JO, Sunmonu TA, Bankole IA, Adekeye A, Abubakar SA. Medication adherence and adverse effect profile of anti-epileptic drugs in Nigerian patients with epilepsy. Neurodegener. Dis. Manag. 8(1), 25-36 (2018).

6. Spreadbury JH, Kipps CM. Understanding important issues in young-onset dementia care: the perspective of healthcare professionals. Neurodegener. Dis. Manag. 8(1), 37-47 (2018).

7. Pelak VS, Hills W. Vision in Alzheimer's disease: a focus on the anterior afferent pathway. Neurodegener. Dis. Manag. 8(1), 49-67 (2018).

8. Miller AE. Teriflunomide in multiple sclerosis: an update. Neurodegener. Dis. Manag. 7(1), 9-29 (2017).

9. Kern R. Biogen's portfolio and research efforts in multiple sclerosis: an interview with Dr Ralph Kern. Neurodegener. Dis. Manag. 7(1), 5-7 (2017).

10. Hendin B, Huang D, Wray $S$ et al. Subcutaneous peginterferon $\beta$-1a injection-site reaction experience and mitigation: Delphi analysis of the ALLOW study. Neurodegener. Dis. Manag. 7(1), 39-47 (2017).

11. Safari R, van der Linden ML, Mercer TH. Effect of exercise interventions on perceived fatigue in people with multiple sclerosis: synthesis of meta-analytic reviews. Neurodegener. Dis. Manag. 7(3), 219-230 (2017).

12. Katzberg HD, Latov N, Francis O, Walker FO. Measuring disease activity and clinical response during maintenance therapy in CIDP: from ICE trial outcome measures to future clinical biomarkers. Neurodegener. Dis. Manag. 7(2), 147-156 (2017).

13. Dinkova-Kostova AT, Kazantsev AG. Activation of Nrf2 signaling as a common treatment of neurodegenerative diseases. Neurodegener Dis. Manag. 7(2), 97-100 (2017).

14. Zesiewicz TA, Chriscoe S, Jimenez T, Upward J, Davy M, VanMeter S. A randomized, fixed-dose, dose-response study of ropinirole prolonged release in advanced Parkinson's disease. Neurodegener. Dis. Manag. 7(1), 61-72 (2017).

15. Zesiewicz TA, Chriscoe S, Jimenez T, Upward J, VanMeter S. A fixed-dose, dose-response study of ropinirole prolonged release in early stage Parkinson's disease. Neurodegener. Dis. Manag. 7(1), 49-59 (2017).

16. Ertekin-Taner N. Identifying therapeutic targets for Alzheimer's disease with big data. Neurodegener. Dis. Manag. 7(2), 101-105 (2017).

17. Moser AD, Epping E, Espe-Pfeifer P et al. A survey-based study identifies common but unrecognized symptoms in a large series of juvenile Huntington's disease. Neurodegener. Dis. Manag. 7(5), 307-315 (2017).

18. Linker R. Foreword. Neurodegener. Dis. Manag. 6(Suppl. 6), 1-2 (2017).

19. Publons. https://publons.com/home/

20. Future Medicine and Future Science Announce New Website Launches. www.future-science-group.com/future-medicine-and-future-science-announce-new-website-launches/

21. Neuro Central. www.neuro-central.com/ 